\title{
STRATEGI KOMUNIKASI DINAS LINGKUNGAN HIDUP KOTA PALU DALAM MENINGKATKAN KESADARAN MASYARAKAT AKAN KEBERSIHAN LINGKUNGAN
}

\author{
Clara Peggy Claudia \\ Program Studi Ilmu Komunikasi FISIP Universitas Tadulako \\ Email: claudiaclarapeggy@gmail.com
}

\begin{abstract}
ABSTRAK
Tujuan penelitian ini yaitu penelitian ini adalah untuk mengetahui Strategi Komunikasi Dinas lingkungan hidup Kota Palu Dalam Meningkatkan Kesadaran Masyarakat Mengenai Kebersihan Lingkungan. Tipe penelitian yang digunakan adalah tipe deskriptif kualitatif. Dasar penelitian pada penelitian ini adalah studi kasus dengan jumlah informan sebanyak 3 (tiga) orang, teknik pengumpulan data yang digunakan adalah observasi dan wawancara. Adapun teknik analisis data yang digunakan adalah deskriptif kualitatif, yakni reduksi data, penyajian data, dan menarik kesimpulan atau verifikasi. Hasil penelitian menunjukkan bahwa strategi komunikasi Dinas Lingkungan Hidup Kota Palu dalam meningkatkan kesadaran masyarakat akan kebersihan lingkungan yakni mengenali sasaran komunikasi yang terdiri atas faktor kerangka referensi khalayak dari latar belakang masyarakat serta faktor situasi dan kondisi. Pengkajian tujuan pesan komunikasi oleh Dinas Lingkungan Hidup Kota Palu umumnya tentang meningkatkan kesadaran masyarakat akan kebersihan lingkungan, pelaksanaan kegiatan dalam meningkatkan kesadaran masyarakat tidak terlepas dari media yakni, panflet, HT (Handy Talkie), aplikasi google maps mobile, whatsapp group.
\end{abstract}

Kata Kunci: Strategi; Komunikasi; Dinas Lingkungan Hidup

Submisission: 26 April 2021

\section{Pendahuluan}

Perkembangan zaman yang semakin maju dan pola konsumsi manusia juga semakin banyak, semuanya serba instan dan higenis baik makanan maupun yang lainnya. Namun dibalik kemudahan dan kehigenisan tersebut banyak masalah yang ditimbulkan. Salah satu diantaranya yaitu sampah.
Sampah, begitu mendengar kata tersebut pikiran kita akan langsung membayangkan pada sesuatu yang berserakan, kotor, menjijikan, bau tidak sedap, barang tidak berguna, dan lain sebagainya. Sehingga sampah menjadi sesuatu yang tidak menarik dan harus disingkirkan supaya tidak menganggu kenyamanan lingkungan. Barang- 
barang yang sudah tidak dipergunakan lagi, maupun bahan sisa dari proses kegiatan seharihari adalah sumber yang tidak dapat kita hindari, akhirnya kita sendirilah sebagai produsen utama sampah. Sampah yang kita hasilkan akan segera memenuhi tempat-tempat sampah disekitar rumah kita, setelah tempat sampah kita penuh, sampah tersebut kita buang ke tempat pembuangan sampah akhir. Bisa kita bayangkan, bila kegiatan produksi sampah ini berlangsung setiap hari dan terus menerus, berapa jumlah sampah yang akan menggunung ditempat-tempat pembuangan akhir.

Kebersihan merupakan suatu hal yang mempengaruhi kualitas hidup di masyarakat, terwujudnya lingkungan yang bersih salah satu faktor penunjang kesehatan mahluk hidup. Namun permasalahan saat ini untuk mewujudkan lingkungan yang bersih, tidak terlepas kaitannya dengan masalah sampah yang dari hari ke hari semakin menumpuk, hal ini disebabkan karena pertambahan penduduk yang semakin meningkat dan disertai juga dengan aktivitas manusia yang semakin berkembang dan pembangunan yang dilakukan juga terus meningkat, sehingga bertambahnya volume sampah dan jenis sampah yang beragam. Akibatnya, terjadi penumpukan sampah yang menimbulkan bau yang tidak sedap dan mengurangi tingkat kesuburan tanah. Untuk menanggulangi masalah ini peran dan kesadaran masyarakat diperlukan untuk mengurangi dan mengelola sampah. Selain peran masyarakat, peran Dinas Lingkungan Hidup sebagai salah satu instansi pemerintahan yang sangat penting dalam mengelola sampah agar terciptanya lingkungan yang bersih dan nyaman.

Menjaga kebersihan lingkungan adalah tanggung jawab kita semua sebagai manusia. Dengan lingkungan yang bersih, tentu akan menciptakan kenyamanan dan keindahan dalam kehidupan manusia. Salah satu yang dapat merusak kenyamanan dan keindahan lingkungan ialah sampah. Sampah merupakan masalah yang dihadapi hampir negara-negara di dunia tidak hanya negara berkembang tetapi juga negara maju. Sampah ialah suatu bahan yang terbuang atau dibuang dari sumber hasil aktivitas manusia maupun alam yang belum memiliki nilai ekonomis. Pengelolaan sampah yang tidak diurus dengan baik akan mengakibatkan masalah yang besar.

Sampah telah menjadi masalah klasik di Indonesia termasuk salah satunya di Kota Palu. Sampah dengan segenap permasalahan yang dihadapi Kota Palu tidak hanya mempengaruhi estetika, kebersihan, dan kenyamanan kota, juga berpengaruh terhadap kesehatan penduduk dan lingkungan kota sebagai akibat dari produksi dan polusi sampah. Untuk mewujudkan lingkungan Kota Palu yang sehat dan bersih dari sampah sehingga penduduknya merasa nyaman dan bebas dari polusi sampah,diperlukan pengelolaan sampah secara terpadu oleh semua pihak.

Pemerintah Daerah mempunyai tugas menjamin terselenggaranya pengelolaan sampah yang baik dan berwawasan lingkungan. Berdasarkan Peraturan Daerah Kota Palu Nomor 9 Tahun 2011 tentang Pengelolaan 
Sampah, pada Bab 3 Pasal 5 poin (a) menyatakan bahwa pemerintah daerah berwenang untuk memfasilitasi, mengembangkan, dan melaksanakan upaya pengurangan, penanganan, dan pemanfaatan sampah. Berdasarkan pasal tersebut, sudah menjadi kewenangan pemerintah daerah untuk pelaksanaan upaya pengurangan sampah. Salah satu upaya yang dilakukan Pemerintah Daerah ialah membuat suatu kebijakan guna mengurangi sampah. Hal ini sesuai dengan Pasal 6 Peraturan Daerah Kota Palu Nomor 9 Tahun 2011 bahwa dalam menyelenggarakan pengelolaan sampah, Pemerintahan Daerah mempunyai kewenangan menetapkan kebijakan dan strategi pengelolaan sampah berdasarkan kebijakan nasional dan provinsi.

Adapun tugas pokok dan fungsi dari Dinas Lingkungan Hidup Kota Palu yaitu membantu Walikota dalam menyelenggarakan sebagian urusan rumah tangga Kota Pangkalpinang hal ini dilakukan untuk melaksanakan kewenangan otonomi daerah di bidang kebersihan di lingkungan pemerintah Kota Palu yang didasarkan pada kebijakan yang ditetapkan oleh Walikota sesuai peraturan perundang- undangan yang berlaku. Oleh karena itu, peran Dinas Lingkungan Hidup sangat dibutuhkan oleh semua masyarakat, guna menciptakan lingkungan yang bersih, sehingga para pegawai di instansi tersebut mampu bekerja secara optimal untuk meningkatkan kinerja pelayanannya kepada masyarakat khususnya masyarakat Kota Palu.

\section{Tinjauan Pustaka \\ Strategi Komunikasi}

Strategi Komunikasi adalah metode, tehnik, atau cara komunikasi bekerja sehingga kita dapat mencapai tujuan yang telah ditetapkan tersebut.
Jika komunikator ingin mencapai tujuan yang telah direncanakan, maka dia akan melaksanakan seperangkat tugas tertentu (fungsi) dan untuk mempercepat, memperlambat membuat efektif atau tidak efektif, mendorong atau menghambat tercapainya tujuan maka komunikator menetapkan strategi (Liliweri, 2011: 133).

Berhasil tidaknya kegiatan komunikasi secara tidak langsung banyak ditentukan oleh Strategi Komunikasi. Peranan dan fungsi komunikasi yang dirancang komunikator untuk mencapai komunikasi yang sesuai. Mengirimkan informasi agar komunikasi mengetahui, mengirimkan pesan yang mendidik agar komunikan mengerti, mengirimkan pesan yang menghibur agar komunikan menikmati, mengirimkan pesan persuasive agar komunikan berubah sikap, agar pesan-pesa tersebut dapat dengan mudah diterima dengan baik maka perlu menyusun strategi. Semua aktivitas yang berhubungan dengan komunikasi sudah tentu tidak asal jadi, komunikasi manusia harus direncanakan, diorganisasikan, di tumbuhkembangkan agar menjadi salah satu komunikasi yang lebih berkualitas, salah satu langkah terpenting adalah menetapkan "Strategi Komunikasi" (Liliweri, 2011: 218)

Menurut Liliweri (2011:240) :

a. Strategi yang mengartikan, menjelaskan, dan mempromosikan suatu visi komunikasi dan satuan tujuan komunikasi dalam suatu rumusan yang baik. 
b. Strategi untuk menciptakan komunikasi yang konsisten, komunikasi yang dilakukan berdasarkan satu pilihan (keputusan) dari beberapa opsi komunikasi.

c. Strategi berbeda dengan taktik, strategi komunikasi menjelaskan tahapan konkret dalam rangkaian aktivitas komunikasi yang berbasis pada satuan teknik bagi pengimplementasikan tujuan komunikasi. Adapun taktik adalah satu pilihan tindakan komunikasi tertentu berdasarkan strategi yang telah ditetapkan sebelumnya.

Menurut Henry Mintzberg dalam Liliweri (2011:242) menyatakan bahwa strategi terbagi atas empat (4) yaitu :

a. Strategi adalah sebuah rencana "bagaimana" suatu cara untuk mendapatkan sesuatu dari sini atau dari sana

b. Strategi adalah pola tindakan dari waktu ke waktu

c. Strategi adalah suatu posisi yang mencerminkan keputusan untuk menawarkan produk atau jasa tertentu di pasar tertentu.

d. Strategi adalah perspektif terhadap visi dan terhadap misi.

Menurut Middleton dalam Cangara (2013:61), Strategi komunikasi adalah kombinasi yang terbaik dari semua elemen komunikasi mulai dari komunikator, pesan, saluran (media), penerima sampai pada pengaruh (efek) yang dirancang untuk mencapai tujuan komunikasi yang optimal. Burnet dkk dalam Efendy (2011:32) dalam buku mereka yang berjudul "Techniques for Effective Communication" bahwa sentral dalam kegiatan komunikasi yang juga termasuk dalam strategi komunikasi adalah:

1.To Secure Understanding, yaitu untuk memastikan bahwa komunikasi mengerti pesan yang diterimanya

2. To Establish AcceptNCE, yaitu pengertian dan penerimaan mereka harus dibina dalam artian dipelihara, dan

3.To Motivate Action, yaitu memotivasi komunikan untuk melakukan tindakan

\section{Tujuan Strategi Komunikasi}

Adapun tujuan strategi komunikasi adalah:

a. Memberitahu (Announcing), yaitu pemberitahuan tentang kapasitas dan kualitas informasi

b. Memotivasi (Motivating), informasi yang disampaikan dapat memberikan motivasi kepada audiens

c. Mendidik (Educating), informasi disampaikan harus bersifat mendidik

d. Menyebarkan informasi (Informning), menyebarkan inforasi kepada masyarakat atau audiens yang menjadi sasaran, informasi yang disebarkan informasi yang spesifik dan aktual, sehingga dapat digunakan

(www.kajianpustaka.com).

\section{Strategi Komunikasi yang Efektif}

Strategi komunikasi akan efektif apabila terjadi pemahaman yang sama merangsang pihak lain 
untuk berpikir atau melakukan sesuatu. Menurut Cultip dan Center (Mulyana, 2008:113) strategi komunikasi yang efektif harus dilakukan melalui empat tahap yakni:

1. Fact Finding, mencari dan mengumpulkan fakta dan data sebelum seseorang melakukan kegiatan sosialisasi.

2.Planning, berdasarkan data dan fakta yang diperoleh dibuatlah rencana kerja mengenai strategi komunikasi yang sekiranya tepat sesuai dengan daya nalar komunikannya.

3. Communicating, setelah semua rencana telah disusun maka dilakukan komunikasi

4.Evaluating, penilaian penganalisaan kembali mengenai kegiatan strategi komunikasi yang telah dilakukan. Hasil analisis dan evaluasi ini digunakan untuk menyempurnakan kegiatan strategi komunikasi lainnya

Strategi komunikasi pada hakekatnya adalah perencanaan (planning) dan manajemen (management) untuk mencapai suatu tujuan. Strategi komunikasi ini harus mampu menunjukkan bagaimana operasionalnya secara praktis yang harus dilakukan, dalam arti kata bahwa pendekata (approach) bisa berbeda sewaktu-waktu bergantung pada situasi dan kondisi (Effendy, 2016:32).

\section{Komunikasi}

Komunikasi merupakan kebutuhan dasar hidup manusia. Melalui komunikasi seseorang dapat menetapkan sebuah keputusan, mengemukakan permasalahan, memecahkan masalah, memberikan infomasi, melepaskan ketegangan, memberikan pengetahuan, dan menanamkam keyakinan. Pada umumnya, komunikasi dilakukan dengan menggunakan kata-kata (lisan) yang dapat dimengerti oleh kedua belah pihak. Apabila tidak ada bahasa verbal yang dapat dimengerti oleh keduanya, komunikasi masih dapat dilakukan dengan menggunakan gerak-gerik badan, menunjukkan sikap tertentu, misalnya tersenyum, menggelengkan kepala, mengangkat bahu. Cara seperti ini disebut komunikasi dengan bahasa nonverbal (Majid, 2016).

Kata komunikasi atau communication dalam bahasa inggris berasal dari bahasa latin communis yang artinya "sama", communico, communication, atau communicare yang berarti "membuat sama" (to make common). istilah pertama (communis) adalah istilah yang paling sering sebagai asal usul komunikasi,yang merupakan akar dari kata-kata Latin lainnya yang mirip. Komunikasi menyarankan bahwa suatu pikiran, suatu makna, atau suatu pesan dianut secara sama. (Mulyana, 2005:4).

Melalui komunikasi, sikap dan perasaan seseorang atau sekelompok orang dapat dipahami oleh pihak lain. Akan tetapi, komunikasi hanya akan efektif apabila pesan yang disampaikan dapat ditafsirkan sama oleh komunikan. Sebuah komunikasi bukan hanya sekedar pertukaran kata. Setiap perilaku memiliki potensi komunikasi. tersenyum, merapikan rambut atau pakaian ketika ada orang lain, menatap, mengangguk, mengerutkan kening, menutup hidung ketika ada orang merokok di dekat 
dan berbagai contoh perilaku lainnya. Komunikasi merupakan perwujudan dari ekspresi manusia tentang apa yang dipikirkan dan dirasakannya baik dalam bentuk verbal maupun nonverbal. Mulyana (2005: 45).

\section{Metode Penelitian}

Tipe penelitian yang digunakan adalah penelitian kualitatif, dimana penelitian ini data yang dikumpulkan berupa kata-kata, gambar dan tidak menggunakan perhitungan analisis data statistik. Menurut M. Nazir (2003:17) tujuan deskriptif ini adalah untuk membuat deskripsi, gambaran atau lukisan secara sistematis, faktual dan akurat mengenai fakta-fakta, sifat-sifat serta hubungan antara fenomena yang diselidiki. Dalam penelitian ini bertujuan untuk menggambarkan dan memaparkan atau menerangkan secara lebih baik mengenai "Strategi Komunikasi Dinas Lingkungan Hidup Kota Palu dalam meningkatkan kesadaran masyarakat akan kebersihan lingkungan".

\section{Hasil Penelitian Dan Pembahasan}

Pelaksanaan pembangunan disuatu wilayah merupakan wujud eksistensi pemerintah di wiliyah tersebut. Menurut Saul M Katz pembangunan merupakan perubahan yang berlangsung secara luas dalam masyarakat bukan hanya sekedar perubahan pada sektor ekonomi saja, tetapi mencakup masalah-masalah perubahan ekonomi, sosial, politik dimana masalah tersebut saling berhubungan satu sama lain. Pembangunan adalah proses perubahan terencana yang merupakan interaksi antar banyak pihak dalam rangka mengupayakan perbaikan mutu hidup masyarakat dalam menggunakan teknologi yang terpilih, sehingga komunikasi pembangunan dapat diartikan sebagai proses interaksi seluruh pemangku kepentingan pembangunan yang terdiri dari pemerintah, tokoh masyarakat, tokoh agama, LSM dan kelompok/organisasi sosial.

Komunikasi yang dilakukan memiliki tujuan yang jelas yaitu mempengaruhi orang lain atau audiens dengan menampiklkan komunikator, rancangan pesan, media yang dapat mempersuasi komunikan dan mengandung unsur-unsur komunikasi, Cangara (2016:24-27) yaitu:

1. Sumber, pembuat atau pengirim informasi dalam hal ini Dinas Lingkungan Hidup Kota Palu yang menyampaikan pesan khususnya kepada masyarakat terkait meningkatkan kesadaran masyarakat akan kebersihan lingkungan.

2. Pesan, informasi yang disampaikan Dinas Lingkungan Hidup Kota Palu terutama Bidang Pengelolaan Sampah kepada masyarakat terkait program sosialisasi dalam meningkatkan kesadaran masyarakat akan kebersihan lingkungan yang disampaikan secara tatap muka.

3. Media, alat yang digunakan Bidang Pengelolaan Sampah dalam menyampaikan pesan kepada masyarakat, Bidang Pengelolaan Sampah menggunakan media sosial dan internet seperti memakai aplikasi Google Maps Mobile 
dan WhatsApp grup dalam membantu penyampaian pesan kepada masyarakat.

4. Penerima, pihak yang menjadi sasaran program sosialisasi dalam meningkatkan kesadaran masyarakat akan kebersihan yang dijalankan Dinas Lingkungan Hidup Kota Palu di Bidang Pengelolaan Sampah.

5. Pengaruh, perbedaan yang dirasakan masyarakat sebelum dan sesudah menerima program dari Dinas Lingkungan Hidup Kota Palu, dari hasil penelitian menunjukkan bahwa ada beberapa masyarakat yang merasakan dari program sosialisasi dalam meningkatkan kesadaran masyarakat akan kebersihan lingkungan.

6. Umpan balik, respon atau pengaruh yang ditujukan masyarakat setelah menerima program Dinas Lingkungan Hidup Kota Palu, dari hasil penelitian beberapa masyarakat juga menunjukkan respon negatif terkait cara berkomunikasiBidang

Pengelolaan Sampah dalam menyampaikan informasi dengan menggunakan bahasa yang sudah dimengerti.

Strategi komunikasi dan perencanaan diperlukan dalam proses pembangunan agar dapat menciptakan komunikasi yang efektif. Komunikasi perlu ditempatkan pada fungsinya, bukan hanya untuk membangkitkan kesadaran, memberi informasi, mempengaruhi atau mengubah perilaku, melainkan komunikasi juga berfungsi untuk mendengarkan mengeksplorasi lebih dalam, memahami, memberdayakan, dan membangun konsesus untuk perubahan, karena itu komunikasi diperlukan untuk mendukung proses pembangunan. Strategi komunikasi Dinas Lingkungan Hidup Kota Palu dalam meningkatkan kesadaran masyarakat akan kebersihan dilakukan oleh yang diberi tugas, tanggung jawab, wewenang secara penuh oleh pejabat yang berwenang untuk melaksanakan tuigas dan kegiatan penyuluhan, pelayanan, evaluasi dalam program sosialisasi dalam meningkatkan kesadaran masyarakat akan kebersihan.

Seperti yang dikatakan Burnet dkk dalam Effendy (2011 : 32) bahwa sentral dalam kegiatan komunikasi yang termasuk dalam strategi komunikasi yaitu: (1) To Secure Understanding, yaitu untuk memastikan bahwa komunikan mengerti pesan yang diterimanya, namun yang peneliti dapat di lapangan bahwa ada beberapa komunikator (Bidang Pengelolaan Sampah) yang menyampaikan pesan kepada komunikan (masyarakat) masih belum bisa diterima. Kadang Bidang Pengelolaan Sampah tersebut menggunakan bahasa yang tidak dimengerti masyarakat (2) To EstablishAcceptance, yaitu pengertian dan penerimaan mereka harus dibina dalam artian dipelihara, yang peneliti dapatkan di lapangan bahwa untuk pembinaan bidang pengelolaan sampah punya kegiatan yang melibatkan masyarakat seperti sosialisasi, dari kegiatan tersebut msasyarakat bisa dilibatkan dan diberikan pengertian terkait pentingnya menjaga kebersihan akan 
lingkungan hidup dan (3) To Motivate Action, yaitu memotivasi komunikan untuk membuang sampah pada tempatnya dan menjaga kebersihan lingkungan, Bidang Pengelolaan Sampah memotivasi masyarakat melalui kegiatan sosialisasi dan melalui aplikasi yang sudah disepakati agar masyarakat mau membantu dan bekerja sama dengan dalam menjaga kebersihan lingkungan, menjelaskan pentingnya menjaga kebersihan lingkungan sekitar untuk diri sendiri dan orang lain agar bisa menciptakan lingkungan yang bersih dan nyaman berdasarkan tujuan dari adayanya sosialisasi tersebut.

Program sosialisasi adalah program yang dikeluarkan Dinas Lingkungan Hidup khususnya bidang pengelolaan sampah dalam rangka meningkatkan kesadaran masyarakat akan kebersihan lingkungan. Hal ini dilakukan untuk kesejahteraan masyarakat, yang sangat bermanfaat untuk terhindar dari penyakit dan nyaman dengan lingkungan sekitarnya. Program sosialisasi yang dibuat Dinas Lingkungan Hidup dan Bidang Pengelolaan Sampah ini merupakan suatu upaya dalam melakukan pembangunan bagi masyarakat itu sendiri. pembangunan tersebut adalah sebuah hubungan yang saling berkaitan dalam rangka melakukan pengarahan, mengendalikan dan juga mewujudkan setiap bentuk perubahan yang mengarah kepada kebutuhan masyarakat.

Pelaksanaan sosialisasi yang dilakukan oleh Dinas Lingkungan Hidup dan bidang pengelolaan sampah, bertujuan untuk menginformasikan dan mengajak memahami, mengikuti dan melaksanakan sosialisasi dalam upaya mencapai lingkungan yang bersih. Untuk mencapai tujuan tersebut maka petugas sosialisasi paling tidak ada tiga kemampuan yang harus dimiliki oleh Dinas Lingkungan Hidup Kota Palu :

1. Kemampuan Berkomunikasi, seorang Dinas Lingkungan Hidup harus bisa berkomunikasi dengan baik dan benar sehingga mampu menyampaikan informasi kepada khalayak/sasaran dan harus mampu dalam melakukan trik-trik komunikasi sekaligus mampu menerjemahkan pesan kedalam bahasa yang lebih akrab dengan masyarakat setempat sehingga masyarakat bisa lebih mudah mengerti dengan apa yang disampaikan. Namun berdasarkan temuan di lapangan bidang kebersihan yang turun langsung bertemu dengan masyarakat belum mampu berkomunikasi dengan baik dengan masyarakat, sehingga terjadi kesalahpahaman penyampaian pesan yang merupakan hambatan antara Dinas Lingkungan Hidup dan masyarakat.

2. Kemampuan bekerja, dengan data Dinas Lingkungan Hidup khususnya bidang pengelolaan sampah harus bisa menguasai proses pengumpulan data, pengelolaan, penyajian, dan juga pemanfaatan data kependudukan/masyarakat, demografi, serta data wilayah dan juga potensinya, termasuk 
data tokoh masyarakat setempat dan juga kondisi sosial budaya masyarakat setempat. Berdasarkan temuan di lapangan, hal ini belum tercapai, karena belum semua pihak Dinas Lingkungan Hidup yang mampu menguasai pengelolahan dan penyajian data mereka baru mampu menguasai proses pengumpulan data dan pemanfaatan datatokoh masyarakat.

3. Kemampuan membangun jaringan dan berkoordinasi dengan berbagai pihak Dinas Lingkungan Hidup khususnya Bidang Pengelolaan Sampah harus mampu membangun jaringan/koordinasi dengan berbagai pihak, tidak hanya dengan unsur pemerintah, tetapi sosialisasi harus melibatkan tokoh masyarakat atau orang-orang yang memiliki pengaruh dimasyarakat, hal ini dimaksudkan agar tujuan sosialisasi dapat tercapai sesuai harapan yang diinginkan. Hal ini sudah dilakukan Bidang Pengelolaan Sampah dengan melibatkan masyarakat dan kelurahan untuk membantu mereka dalam kegiatan sosialisasi penyampaian informasi melalui internet maupun melalui media sosial.

Dinas Lingkungan Hidup khususnya Bidang Pengelolaan Sampah diharapkan mampu menginformasikan dan mengajak masyarakat agar dapat berpartisipasi dalam program yang sudah direncanaka pemerintah terkait meningkatkan kesadaran masyarakat akan kebersihan lingkungan sesua dengan tujuan strategi komunikasi yaitu:

1. Membantu (Annoucing), yaitu memberitahukan tentang manfaat dan pentingnya membuang sampah pada tempatnya, karena membuang sampah pada tempatnya itu sendiri baik untuk diri sendiri dan lingkungan sekitar.

2. Memotivasi (Memotivating), informasi yang disampaikan dinas kebersihan diharapkan dapat meningkatkan kesadaran masyarakat akan kebersihan lingkungan.

3. Mendidik (Educating), informasi yang disampaikan diharapkan dapat merubah pola pikir masyarakat tentang pentingnya menjaga kebersihan lingkungan sekitar.

4. Menyebar informasi (Informating), informasi yang disebarkan bersifat persuasif (membujuk) masyarakat akan pentingnya menjaga kebersihan lingkungan sekitar.

Terkait dengan pencapaian tujuan tersebut maka dalam pelaksanaan sosialisasi, Dinas Lingkungan Hidup Kota Palu menerapkan berbagai strategi atau pendekatan yang mudah dan efektif serta memperhatikan kebutuhan masyarakat yang menjadi sasaran sosialisasi. Hal ini sebagai bentuk keterlibatan membaur dengan masyarakat agar di dalam melakukan komunikasi dengan masyarakat lebih mudah diterima dan memahami 
keinginan dari masyarakat yang sesuai dengan tujuan utama komunikasi (Liliweri, 2011:128), yaitu membangun atau mengelola relasi antarpersonal, membantu orang lain dengan bermain/bergurau.

Berdasarkan Strategi

komunikasi menurut Cutlip dan Center (Mulyana, 2008:113) terdapat empat (4) tahap yaitu: (1) Fact Finding (2) Planning (3) Communicating (4) Evaluating. Dari hasil pengamatan dan wawancara peneliti melihat dari keempat tahap strategi komunikasi tersebut. Dinas Lingkungan Hidup Kota Palu dan bidang pengelolaan sampah sudah hampir melakukan semua tahap perencanaan tersebut namun ada beberapa tahap yang tidak lakukan seperti pembuatan brosur dan poster, tahap-tahap tersebut dilakukan oleh Dinas Lingkungan Hidup Kota Palu khususnya dibagian kasubag keuangan karena mereka yang mengadakan pembuatan retribusi, bidang pengelolaan sampah hanya membantu menjalankan tahap-tahap yang sudah ditentukan tersebut.

Proses komunikasi tidak selamanya berjalan lancar, banyak sekali terdapat kesalahan-kesalahan penyampaian, penerimaan, bahkan kesalahan ketika harus mengartikan pesan atau informasi yang diterima. Hambatan komunikasi yang terjadi di Dinas Lingkungan Hidup dalam melakukan penyuluhan terkait meningkatkan kesadaran masyarakat akan kebersihan lingkungan adalah hambatan yang terjadi dari komunikator, dimana masih ada anggota bidang pengelolaan sampah yang kurang akan pelatihan berkomunikasi, sehingga cara mereka berkomunikasi ke masyarakat itu kadang sulit untuk dicerna dan diterima oleh masyarakat, kemampuan menjadi penyampai pesan masih kurang sehingga menyebabkan gangguan semantik dimana pesan informasi yang disampaikan menjadi sulit untuk dipahami karena adanya perbedaan bahasa antara komunikator dan komunikan yang menyebabkan masyarakat kurang paham maksud yang disampaikan bidang pengelolaan sampah. Selain komunikator, hambatan juga terjadi pada media yang digunakan untuk menyampaikan pesan seperti kurangnya penyampaian informasi melalui media cetak poster dan brosur, penyebaran media cetak tersebut dilakukan hanya bagian kelurahan maupun tempat sosialisasi sehingga masyarakat yang berada jauh dari tempat tersebut sedikit sulit mendapatkan informasi tentang meningkatkan kesadaran masyarakat akan kebersihan lingkungan. Hambatan yang selanjutnya terjadi dari komunikan sendiri yang merupakan sasaran dari program sosialisasi seperti kurangnya pemahaman dan daya tangkap terkait informasi yang di sosialisasikan sehingga masih banyak masyarakat yang belum mengerti apa yang disampaikan.

\section{Kesimpulan}

Berdasarkan hasil penelitian observasi dan wawancara di Dinas Lingkungan Hidup mengenai "Strategi Komunikasi Dinas Lingkungan Hidup Kota Palu dalam Meningkatkan Kesadaran Masyarakat akan Kebersihan Lingkungan Hidup" maka dapat disimpulkan sebagai berikut. 
Program sosialisasi yang dilaksanakan Dinas Lingkungan Hidup Kota Palu yaitu dalam bentuk sosialisasi langsung ke masyarakat (Kelurahan) dengan melakukan strategi komunikasi menurut Culti dan Center. Selain sosialisasi langsung, penyebaran informasi terkait program sosialisasi juga dilakukan melalui sosial media dan internet yang berupa aplikasi Google maps mobie, serta media pendukung lainnya yang digunakan pada saat sosialisasi yaitu WhatsApp group dan Facebook.

a. Fact Finding, dinas lingkungan hidup kota palu melakukan analisis (riset) untuk mengetahui seberapa besar tingkat kesadaran masyarakat

terhadapkebersihan

lingkungan, karena dijalan soekarno hatta masih banyak sampah berserakan, serta masalah yang terdapat pada saat riset ialah sulitnya menyampaikan informasi secara langsung mengenai buang sampah pada tempatnya.

b. Planning, pada tahap planning Dinas Lingkungan Hidup Kota Palu menentukan komunikator yaitu memilih orang-orang yang mampu berkomunikasi secara persuasif serta sudah berpengalaman di bidangnya seperti Kepala Dinas Lingkungan Hidup Kota Palu maupun Kepala Bidang Pengelolaan Sampah. Pada tahap menentukan komunikan Dinas Lingkungan Hidup Kota Palu dan Bidang
Pengelolaan Sampah memilih masyarakat yang menjadi sasaran dari program sosialisasi. Pada tahap menentukan tujuan Dinas Lingkungan Hidup Kota Palu melihat permasalahan berdasarkan hasil riset. Sedangkan, pada tahap menentukan pesan Bidamg Pengelolaan Sampah tidak melakukan, yang menentukan ialah Kepala Dinas Lingkungan Hidup Kota Palu, Bidang Pengelolaan Sampah hanya membantu menjalankan pesan yang ada dalam program dari Kepala Dinas Lingkungan Hidup Kota Palu.

c. Communicating, pada tahap ini juga Dinas Lingkungan Hidup Kota Palu sudah melakukannya tetapi bahasa yang disampaikan kurang dimengerti oleh masyarakat (Kelurahan) sehingga penyampainnya kurang dimengerti.

d. Evaluating, evaluasi yang dilakukan Dinas Lingkungan Hidup Kota Palu terhadap masyarakat dan melihat data masyarakat dari kelurahan. Evaluasi terhadap komunikator juga dilakukan dengan melihat sejauh mana pengetahuan komunikator dlam menyampaikan pesan kepada masyarakat. Serta evaluasi terhadap media untuk melihat berapa banyak masyarakat yang bisa menerima dan mencerna terkait informasi/pesa yang disampaikan terkait program sosialisasi terkait program 
sosialisasi melalui internet, sosial media maupun bertatap muka.

Hambatan yang terjadi dalam pelaksanaan program sosialisasi berupa hambatan pada komunikator yaitu penggunaan bahasa yang berbeda antara sosialisasi dan masyarakat, kemampuan berkomunikasi yang kurang karena kurangnya pelatihan. Hambatan pada media juga terjadi yaitu penyebaran informasi melalui media cetak dan poster masih kurang dan penempatan bak sampah yang masih terlalu jauh dari tempat tinggal masyarakat. hambatan pada komunikan yaitu kurangnya kemampuan dalam menerima dan mencerna informasi/pesan dan pengetahuan menggunakan aplikasi google maps mobile yang menyebabkan masyarakat kurang paham dalam penggunaan aplikasi terlebih bagi orang tua yang berusia lanjut.

\section{Referensi}

Blundel, Richard,2004. Effective Organizational Communication Perspective, Princples and Practices, Second Ed Prentice Hall

Cangara, Hafied. 2014. PerencanaanDan Straregi

Komunikasi. Jakarta PT Rajagrafindo Persada

Cangara, Hafied. 2016. Pengantar Ilmu Komunikasi. Jakarta Rajawali Pers

Effendy, Onong Uchjana 2011. Teori

Dan Praktek. Bandung: Remaja

Rosdakarya. 2017. Ilmu

Komunikasi
Herimanto, Bambang \& Indrojono. 2005. Komunikasi Bisnis, Yogyakarta: Amara Books

Liliweri, Alo. 2011. Komunikasi: Serba Ada, Serba Makna. Jakarta: Kencana.

Majid, M. I. R. (2016). Pengaruh Komunikasi Kepala Sekolah Terhadap Profesionalisme Guru dan Kinerja Pegawai di MTs Negeri Kendal. Journal of Chemical Information and Modeling, 53(9), 1689-1699.

Muhammad, A. 2011. Komunikasi Organisasi. Jakarta: Bumi Aksara.

Moleong,J. 2000. Metode Penelitian Kualitatif. Bandung PT. Remaja Rosdakarya

M.A, Morrisan. 2010. Periklanan : Komunikasi Pemasaran Terpadu. Jakarta: Kencana

Mulyana, Deddy. 2007. Ilmu

Komunikasi: Suatu Pengantar.

Bandung: Remaja Rosdakarya.

Ruslan Rosady, 2002, Kiat dan Strategi Kampanye PR edisi Revisi. PT. Raja Grafindo Persada.

Siagian, Sondang. 2014. Manajemen Strategi. Jakarta. Bumi Aksara

2009. Dimensi-dimensi Komunikasi. Bandung: PT. Citra Aditya Bakti. 